\title{
Paradigma Hubungan antara Kekuasaan Negara dan Perlindungan HAM Di Indonesia
}

\author{
Sri Hastuti Puspitasari
}

\begin{abstract}
In fact, the existence of changes on the rules of Human Right at constitution 1945 get a proper moment because, at that time, Indonesia have fundamental changes from the authotarian regime to democratic regime and in general, the states in being fundamental changes in their state life is followed by the constitutional changes. But the changes of the constitution would be meaningful if it is followed by the commitment all parties in enforcing the Human Right, and the beginning is on the legislative organ who has responsible to respond the problem of Human Right by creating legal instrument for Human Right protection.
\end{abstract}

\section{Pendahuluan}

Pandangan negara sebagai organisasi kekuasaan hampir tidak terbantahkan sebab di dalam negaralah terdapat kekuasaan. Keberadaan negara sebagai organisasi kekuasaan bukannya tanpa risiko, sebab pada saat negara memonopoli seluruh kekuasaan maka pada saat itu negara sekaligus mereduksi hak masyarakat atas kekuasaan. Kemudian pada saat hak masyarakat sudah direduksi oleh negara, maka muncullah negara yang sangat kuat lalu pada saat yang bersamaan masyarakat sudah tidak punya kekuasaan lagi untuk mengontrol.
Negara sendiri menciptakan alat-alatnya untuk melaksanakan kekuasaan secara represif, dan ketika hal itu terjadi maka segala bentuk pelanggaran hak asasi manusia sukar dihindari. Di sinilah letak persoalannya mengapa pada akhirnya masyarakat menggugat negara. Jawabannya ada pada asumsi bahwa negara, sebagai institusi kekuasaan, pada mulanya telah membawa potensi ketidaknetralan, seperti yang dikatakan oleh Andrew Vincent:

"The State is neither a neutral institution which we can afford to ignore nor has it arisen out pure chance or accident. The are customery features which have become about slowly by accretion ${ }^{n t}$

\footnotetext{
'Andrew Vincent, Theory of The State (New York: Basil Blackwell, 1987), hlm.3
} 
Selain itu negara cenderung memonopoli kekuasaan dan menggunakan kontrol yang berlebihan terhadap masyarakat, dengan dalih untuk menciptakan internal order dan menjalankan fungsi pertahanan (fungsi ketertiban dan mempertahankan diri). Meskipun telah ada pebatasan kekuasaan oleh hukum, namun hukum itu sendiri dapat dilanggar oleh negara sebab negara secara faktual memonopoli public power. Lebih lanjut Andrew Vincent mempertajam opini tersebut:

"It is generally true that the state have the maximal control over resource and force. At the same time it is not simply a power system. The force of the state are regulated by rules, which of course can be distorted. However the monopoly of force is tied to specific ends, namely the maintenance of internal order and external defence. The nation of intern order and defence are open to interpretation. The idea of ligitimacy is important here. Since force exercise by the State is usually recognized by the population as distinct from other types of force. The State posseses authority to carry out action. Its monopoly is recognized formally' as necessary and de jures

Dalam konteks hubungan sosial diskursus mengenai Hak Asasi Manusia (HAM) pada dasarnya berangkat dari asumsi dari Peters, bahwa realitas sosial modern mempunyai sifat yang belum selesai dan telah dipolitikkan. ${ }^{3}$ Sebagal bagian dari realitas sosial modern, hak asasi manusia merupakan persoalan yang akan terus mewarnai kehidupan manusia, dan dapat dipastikan bahwa issu yang selalu menjadi mainstream dalam bentang sejarah perjalanan hidup umat manusia di muka bumi ini adalah issu mengenani HAM. Persoalan HAM menjadi persoalan yang belum selesai sebab kehadirannya tidak saja mengundang perdebatan baik secara teoritis maupun secara empiris. Perdebatan klasik antara universalisme dan relativisme masih menjadi letupan-letupan kecil dalam wacana mengenai HAM. Dalam dataran praktis, persoalan HAM menguat sebab pelaksanaannya melibatkan proses politik. Ketika peroalan HAM dimasukkan dalam instrumen hukum internasional, maka HAM telah dibingkai dalam proses politik sebab perumusan HAM dalam instrumen hukum internasional itu sendiri merupakan proses politik. Pada saat persoalan HAM sampal pada keharusan setiap negara untuk melindungi dan menegakkannya, hal itu juga tidak terlepas dari konteks politik negara yang menjalankannya. Maka dari itu, persoalan HAM selain menjadi persoalan yang belum selesal secara teoritis, dalam dataran empiris bentuk perlindungannya sering dipolitikkan. Contoh nyata sifat dipolitikkan dari HAM ini adalah ketika persoalan HAM menjadi semacam prasyarat bagi pemberian bantuan ékonomi kepada suatu negara.

Dalam pengamatan Escobar dan Alvares (1992), ${ }^{4}$ persoalan HAM ini telah mendapatkan bantuannya dalam gerakan-gerakan sosial

${ }^{2}$ Ibid., hlm. 20

${ }^{3}$ AA. Peters Dan Koesriani, Hukum Dan Perkembangan Masyarakat, (Jakarta, Sinar Harapan, 1988), him 18.

"Escobar Dan Alvares, sebagaimana dikutip oleh Mansour Fakih dalam Jumal UNISIA (1997), melakukan studi tentang fenomina gerakan sosial baru di dunia ketiga. Gerakan ini sangat signifikan dengan pemajuan HAM. 
modern (new sosial movements) yang mempunyai kaitan dengan gerakan lain dalam proses sosial yang luas, yaitu proses sosial yang mewarnai hubungan masyarakat sipil dan negara. Asumsi tersebut ada benarnyajika kita mengamati kemunculan gerakan-gerakan penguatan masyarakat sipil yang disuarakan oleh banyak organisasi non pemerintah. Substansi gerakan-gerakan sosial modern adalah lebih berbasis pada persoalan hak asasi manusia apakah hak politik, hak sipil, hak sosial-ekonomi maupun hak atas lingkungan hidup.

Dari sudut pandang sosiologi, hak asasi manusia yang berbasis pada hak individual tidak terlepas dari sistem negara dan kekuasaan yang dimiliki penguasa politik. Secara kritis, Rhoda E. Howard mengatakan bahwa sistem negara abad dua puluh dan kekuasaan yang dimiliki semua penguasa politik memotivasi pembelaan hak asasi manusia seluruh warga negara. Setiap orang berbeda di dalam otoritas negara dan tidak ada orang atau kelompok orang yang terbatas dari otoritas in ${ }^{5}$. Pernyataan Rhoda E. Howaard tersebut dapat dimaknai bahwa manusia sebagai individu tidak dapat mengelak dari format kehidupan bersama yang terorganisasi melalui mekanisme kekuasaan. Ketika manusia terhegemoni oleh kekuasaan politik dan dalam waktu bersamaan hak-hak individualnya berada pada resiko reduksionis serta perampasan oleh penguasa politik maka muncullah gerakan pembelaan hak asasi yang meluas secara sosial. Gejala ini tidak saja terjadi di masyarakat dunia Barat, yang sering diklaim sebagai tempat kelahiran gagasan hak asasimanusia, tetapi juga terjadi di masyarakat belahan dunia lain.

Gerakan pembelaan hak asasi pada mulanya ditujukan pada hubungan antara masyarakat dan negara. Dalam perkembangannya, menurut Rhoda E. Howard, gambaran sosiologis masyaarakat akhir abad dua puluh memperlihatkan tuntutan manusia akan privasi dan perlindungan individu terhadap negara, masyarakat, bahkan keluarga. Lebih lanjut Howaard mengatakan bahwa pada kenyataannya hak asasi manusia mengimplikasikan bentuk tertentu hubungan individu dengan masyaarakat dan negara. Maka dari itu, sekarang HAM tidak lagi dipandang sebagai persoalan yang tidak hanya terjadi dalam hubungan masyarakat dengan negera tetapi antara anggota masyarakat dengan sesama anggota masyarakat dalam komunitas tertentu dan juga antar individu dalam lingkungan tertentu. Hal itu menampakkan polarisasi gerakan advokasi HAM yang berbasis pada relasi ekonomi, relasi gender, bahkan relasi antar pemeluk agama. Sebagai contoh sekarang terdapat gerakan advokasi HAM yang bertajuk perlindungan hakhak konsumen, advokat HAM terdapat korban kekeraan publik yang sifatnya massif (seperti konflik SARA) maupun advokasi HAM terhadap korban kekerasan domestik (keluarga) yang kebanyakan menimpa kaum perempuan dan anak-anak. ${ }^{6}$

Gambaran di atas menunjukkan adanya

${ }^{5}$ Rhoda E. Howard, HAM, Penjelajahan Dalih Relativisme Budaya (Human Rights and Search for Community) diterjemahkan oleh Nugraha Katjasungkana (Jakarta: Grafiti, 2000), hlm. 2.

${ }^{6}$ Ibid, hlm. 124. 
pergeseran sifat pelanggaran HAM pada masyarakat. Ketika masyarakat masih berada pada tatanan yang sederhana, kemungkinan muncul persoalan pelanggaran HAM yang bercorak horizontal, meskipun frekuensinya sangat minim sebab masyarakat sederhana lebih cenderung menciptakan harmoni dan unsur kebersamaan dan kepentingan kelompok akan menjadi hal yang utama. Pada saat masyarakat telah terikat dengan organisasi kekuasaan bernama negara, terdapat konflik yang bersifat vertikal yang menimbulkan pelanggaran HAM yang coraknya vertikal pula, Tetapl seiring dengan kemajuan masyarakat $k \theta$ arah industrialisasi dimana hubungan kekuasaan yang terjadi bukan sekedar hubungan antara rakyat dengan panguasa negara tetapi juga rakyat dengan penguasa asset ekonomi, maka terdapat konflik sifatnya horisontal, misalnya antara produsen dan konsumen dimana keduanya berstatus sebagai rakyat, sebagai warga negara.

\section{Tantangan Teoritis}

Secara umum, dari sudut pandang teoritis terdapat tiga kategori teori Hak Asasi Manusia secara mendasar. Pertama, Natural Right Theory, Kedua, Positivist Right Theory dan, ketlga, Cultural Realitivist Theory.

Dalam pandangan natural right theory, hak asasi manusia adalah rights belong to all human beings at all times and in all places by virture of being born as human beings. Jadl hak asasi manusia dimiliki oleh manusia sepanjang masa dan di semua tempat ada karena la lahir sebagal umat manusia. Hak tersebut bersifat kodrati bukan berasal darl negara dan bukan pula berasal dari sebuah sistem hukum." Substansi HAM dalam perspektif teori ini adalah hak untuk hidup (right to life), hak kebebasan (right to freedoom) dan hak untuk memiliki (right to have property). ${ }^{9}$

Sementara iitu, kalangan positivist tidak menyetujui bahwa hak asasi bersifat kodrati yang dianggapnya imaginer. Right, then should be created and granted by Constitutions, laws or contracs. ${ }^{10}$ Hak asasi yang nyata mestinya diberikan oleh hukum-hukum yang nyata seperti konstitusi, hukum-hukum maupun kontrak-kontrak.

Teori ketiga tentang hak asasi adalah cul-

${ }^{7}$ Todung Mulya Lubis sebenamya menyatakan 6 (enam) perspektif teori tentang HAM. Di samping ketiga teori yang dikemukakan di atas juga ada hak asasi positif, hak asasi dalam perspektif doktrin Marxist dan hak asasi colectif. Baca dalam Todung Mulya Lubis, in Search of Human Right: Legal-Political Dilemmas of Indonesia's. New Oerder, 1966-1990 (Jakarta: Gramedia Pusataka Utama Dan SPES Foundation 1993), hlm. 15-25. *

${ }^{8} \mathrm{Konsep} \mathrm{HAM} \mathrm{dalam} \mathrm{perspektif} \mathrm{natural} \mathrm{right} \mathrm{theory} \mathrm{ditengarai} \mathrm{mendapat} \mathrm{pengaruh} \mathrm{dari} \mathrm{masih} \mathrm{dianutnya}$ hukum kodrat (natural law) pada abad 18'Masehi. T. Mulya Lubis mencatat, bahwa konsep HAM yang bersifat kodrati dibangun oleh filos of sosial pada abad 18-19 Masehi seperti Locke, Montesquieu, Kant dan Rousseau. Lihat T Mudya Lubis, In Search of.... Ibid, him. 16.

${ }^{\circ}$ Hak-hak tersebut dikemukakan oleh John Locke dalam bukunyaTwo Treaties of Govemment.

${ }^{10}$ Pemikiran ini dibangun dari argumentasi Bentham bahwa Right is a child of law, from real laws come real rights, but fromimaginary law, laws of nature, come imaginary rights. Natural right is simple nonsense, natural and imprescriptible right rethorical nonsense, nonsense upon stills. Sebagaimana dikutip oleh T. Mulya Lubis, In Search of ... Ibid, hlm. 18 
tural relativist theory. Menurut teori ini, hak asasi tidaklah universal. Hak asasi dari perspektif natural right theory pada dasarnya mengabaikan basis sosial budaya yang melahirkan traidisi berbeda. Latar belakang sosial budaya yang berbeda ini melahirkan hak asasi yang sesuai dengan seting sosial budayanya.

Sebenarnya gerakan HAM yang dalam sejarahnya mengalami tantangan teoritis. Howard menjelasan 5 (lima) tantangan teoritis yang muncul pada dasawarsa 1990-an tersebut yaitu: kapitalisme radikal, tradisionalisme, konservatisme reaksioner, kolektivisme kiri dan status radicalism. Golongan kapitalisme radikal menentang gagasan hak ekonomi yang menurut pengikutnya tidak relevan dan idealistis dan hanya hak sipil dan politik yang dianggap hak sejati. Aliran tradisional menyatakan bahwa masyarakat tradisional harus diperbolehkan melanggar HAM manakala hak tersebut bertentangan dengan aturan-aturan tradisional tentang perilaku sosial yang tertata. Mereka merasa terhina dengan HAM yang bersifat universal dan mereka berkencerungan mengutamakan hak kelompok. Aliran konservatisme reaksioner menganggap bahwa individualisme yang berlebihan bertentangan dengan tatanan sosial dan mereka menganggap hak sosial adalah masalah perjuangan pribadi, bukan HAM yang harus dilindungi oleh negara. Sementara itu, aliran kolektivis kiri berargumen bahwa masalah HAM yang paling penting adalah penentuan diri sendiri dan melepaskan diri dari kontrol negara-negara barat serta perusahaan-perusahaan multinasional. Terakhir, tantangan dari golongan Status radicalism. Dalam pandangannya, golongan ini menganggap bahwa adakalanya kelompokkelompok manusia diingkari hak asasinya secara menyeluruh karena identitas atau status sosialnya. Starting point perjuangannya adalah poilitik identitas di mana keanggotaan status seseorang lebih penting dibandingkan identitas individualnya. ${ }^{12}$

Di beberapa negara gerakan perjuangan penegakan HAM diwarnai oleh polarisasi golongan-golongan tersebut di atas, meskipun tidak seluruhnya. Di Indonesia, misalnya. Gerakan yang marak pada penentangan Penanaman Modal Asing (PMA) pada era 70an berbasis pada semangat menentang "imperialisme gaya baru". ${ }^{13}$ Gerakan ini menolak

12 Tantangan teoritis ini muncul terhadap bergulimya prinsip hak asasi manusia internasional PBB. Empat tantangan yang disebut terakhir merupakan tantangan yang muncul dari varisn komunitarian. Baca Rhoda $E$. Howaard, Ibid, hlm. 3-7

${ }^{13}$ Gerakan ini ada hubungannya dengan pemikiran post capitalism dalam studi politik, yang mendiskripsikan asumsi bahwa negara-negara dunia ketiga (post colonialism) dwamai oleh tata hubungan yang tidak seimbang antara eks negara-negara penjajah dengan eks negara-negara yang dijajah. Ketidakseimbangan tersebut melahirkan wacana teori dependen yang mencoba menkonstruksi pemikirannya dengan gambaran bahwa perekonomian intemasional oitandai dengan hubungan yang tak seimbang antara negara-negara kapitalisindustri maju disatu pihak dengan negara-negara terbelakang di pihak lain. Terdapat penyerapan surplus ekonomi dari periferi ke pusat sehingga negara-negara dunia ketiga mengalami perkembangan yang terhambat. Tentang teori dependen lihat dalam Verdi R. Hadis, Politik Pembebasan, Teori-teori Negara Pasca Kolonial, (Yogyakarta: Pustaka Pelajar, 1999), h/m. 3435. 
intervensi asing atas ekonomi dalam negeri dan menganggap PMA merupakan bentuk kontrol negara kapitalis terhadap perekonomian dalam negeri. Pola gerakan mereka hampir mirip dengan varian komunitarian kolektivisme kiriyang berbasis pada hak penentuan diri sendiri dan menetang perusahaan-perusaan multinasional yang dikendalikan oleh negara-negara kapitalis. Pada awal 90-an hingga saat ini, di Indonesia juga marak gerakan hak perempuan dan anak. Gerakan ini muncul karena mereka menjadi kelompok yang menyandang status the second citizen dan keberadaan mereka dipinggirkan oleh sistem kekuasaan negara, sistem ekonomi dan sistem. sosial-budaya. Meski gerakan ini tidak terpola pada salah satu golongan yang disebut Howard, namun pada dasarnya gerakan ini muncul sebagai bentuk perlawanan atas hegemoni dalam hubungan kekuasaan.

Dalam dimensi konseptual, diskursus HAM pernah diwarnai perdebatan yang sangat tajam antara pandangan HAM inndividualistik dan HAM yang komunitarian dan antara pandangan universalisme dan relativisme. Pandangan HAM individualistik sering diklaim sebagai mewakili negara-negara Barat yang basis struktural masyarakatnya individualistik, sementra itu, HAM yang komunitarian sering di cap sebagai yang mewakili Timur, demikian juga pandangan HAM yang universal dan relatif paralel dengan klaim pdangan Barat dan Timur. Diantara pandangan tersebut, hegemoni pandangan universal menembus batas ideologl negara dan menjadi satu-satunya paramenter HAM sedunia. Bagaimana pandangan Indone- sia tentang HAM?

Tampaknya tarik ulur universalisme dan relativisme dalam dataran praktis masih sering terjadi meski secara konseptual perdebatan tentang keduanya sudah dianggap selesai. Melihat heterogenitas bangsa Indonesia, tampak padangan HAM yang dianut mencerminkan relativisme. Hal ini tampak dalam The Jakarta Massages tahun 1993 butir 18 yang menyebutkan sebagai berikut:

"We reaffim that the basic human right and fundamental freedoms are of unifersal validity. We welcome the growing trend towards democracy and commit ourselves to cooperative in protection on human right. We believe that economic and social progress facilitate the achievement of these objection. Now country, however, should use its power to dictate ist consept of democrcy and human right or to impose conditionalities on other. In the promotion and the protection of the se right and freedom, we emphasize the inter-relatedness of the various categories, call for balanced reltionship between individual and community rights, uphold the competence and responsibility of national governments in their implementation. The Non-Aligned countries therefore shall coordinate their position and actively participate in the preparatory work of the second World Confrence on Human Right in June 1993, in order to encsure that the Confrence addreses all apects of human right on the basic universality, indivisibility, Impaartiallity and non selectively. ${ }^{24}$

\footnotetext{
14 Apa yang terdapat di dalam The Jakarta Massage tersebut mencerminkan apayang oleh Muladi cisebut partikularistik relatif. The Jakarta Massage itu sendiri tidak sekedar mengilustrasikan bagaimna pandangan Indonesia mengenal HAM tetapi pesan didalamnya juga merupakan seruan terhadap negara-negara non blok
} 
Secara empiris, gerakan HAM yang muncul sepanjang sejarah selalu mengalami perubahan yang substansial. Seperti yang telah banyak ditulis dalam literatur yang berbicara mengenai HAM, gerakan HAM dapat dikategorikan menjadi beberapa generasi. ${ }^{15}$ Gerakan HAM generasi pertama yang yang bernuansa individualistis berbasis pada hak-hak sipil dan hak-hak politik sebagaimana yang terdapat dalam (Deklarasi Umum Hak Asasi Manusia) DUHAM PBB tahun 1948. Nuansa individualistik ini karena substansi HAM dalam DUHAM dirumuskan dan disusun oleh negara-negara yang menang dalam Perang Dunia II. Gelombang gerakan HAM generasi kedua muncul seiring tuntutan hak sosial, ekonomi dan budaya sebagai bagian dari HAM yang universal. Gelombang kedua ini ditandai dengan ditandatanganinya konvensi hak sosial, ekonomi dan budaya tahun 1966. Gelombang ketiga dari gerakan HAM muncul seiring menguatnya tuntutan negara-negara berkembang agar dapat memperoleh kesempatan yang sama sebagai bangsa. Gelombang ketiga ini ditengarai dengan munculnya hak-hak kolektif dan hak pembangunan pada tahun 1986. ${ }^{16}$ Selanjutnya Jimly Asshiddiqie mengemukakan bahwa pada dasarnya HAM generasi ketiga mempunyai karakteristik yang sama yaitu muncul dalam konteks hubungan yang bersifat vertikal antara pemerintah dan rakyat dan pelanggaran HAM pada generasigenerasi tersebut selalu melibatkan pemerintah. Sekarang ini tampaknya muncul HAM yang dapat dikatakan HAM generasi keempat yang dipicu oleh pola hubungan kekuasaan yang bersifat horizontal dan sebenarnya pola ini

untuk memposisikan diri dan berpartisipasi dalam konfrensi dunia tentang HAM yang kedua di Wina tahun 1993. The Jakarta Massage bukan satu-satunya dokumen yang mengandung pemikiran partikularistik relatif. Ada dokumen dalam Deklarasi Kualalumpur tentang HAM yang dirumuskan oleh Inter-Parliamentary Organization (AIPO) tahun 1993 dan The Vienna Declaration and Programme Of Action yang dihasilkan dari konferensi dunia tentang HAM yang kedua di Wina, 1993. Baca dalam Muladi, Hak Asasi Manusia, Politik dan Peradilan Pidana (Semarang: Universitas Diponegoro, 1997), hlm. 5

15 Tiga generasi HAM dikemukkan oleh Karel Vasak, seorang jurist Perancis. la membagi generasi HAM dilhami oleh slogan revolusi Perancis Liberte.,Egalite, dan Fraternite. Baca Richard Oiere Claude andBurs $\mathrm{H}$. Weston, Human Right in The World Community: Issues and Action (Philadelphia: University of Pennsylvania Press, USA, Second Edition), 1992, him. 18.

${ }^{16}$ Negara-negara berkembang melontarkan kritik terhadap falsafah HAM yang dianut oleh negara-negara maju yang berkisar pada (1) HAM dalam DUHAM terkesan tanpa batas sehingga hukum positif yang bersifat nasional kurang dihargai; (2) HAM ekonomi dan HAM pembangunan negara maju terkesan kurang djpertimbangkan sebagai HAM melainkan sebagai cita-cita semata dan tidak sepenting cita-cita politik; (3) Deklarasi HAM hanya merumuskan hak-hak individu dan melecehkan hak-hak kolektif (hak komunitas, hak keluarga dan hak-hak bangsa-bangsa); (4) Deklarasi HAM mengabaikan ciri khas setiap bangsa dan masyarakat yang seharusnya memungkinkan pelaksanaan HAM yang berbeda di setiap negara. Kekhasan ini menimbulkan relativisme kultural atau partikularistik relatif; (5) panilaian negara-negara maju tentang pelaksanaan HAM bersifatjudgement dan seringkali mengkaitkan dengan syarat tertentu yang melekat pada peerdagangan dan ekonomi. Paparan ini disampaikan oleh Miriam Budiardjo dalam harian Kompas, 1997, sebagaimana dikutip oleh Muladi, Ibid, hlm.xi 
sudah menggejala pada HAM generasi kedua. ${ }^{17}$

Persoalan HAM yang muncul dari hubungan kekuasaan tersebut tidak dapat dipungkiri karena negara banyak dipahami sebagai kondifikasi kekuasaan dari formasi sosial. Justru inilah yang menjadi spesifikasi dari negara sebagaimana dikemukakan oleh Neera Chandoke:18

"spesifikasi negara terletak pada fakta bahwa negara dengan mengkodifikasikan hubungan kekuasaan yang dominan dalam masyarakat, memberi kepastian hubungan sosial, dan dengan demikian memberi sytabilitas dalam masyarakat".

Namun pada dasarnya negara, sebagai kondifikasi kekuasaan dalam hubungan sosial, tidak selalu dapat menjamin adanya stabilitas seringkali menggunakan kekuatankekuatan yang koersif dapat mengarah pada kekuasaan otoriter. Dalam hal ini, enforcement terhadap pengaturan HAM, baik dalam level konstitusi maupun dalam level rules lainnya menjadi sangat urgen.

Dalam bingkai kekuasaan negara sebagai kondifikasi kekuasaan sosial,maka gerakan HAM yang banyak disuarakan oleh kelompokkelompok pejuang HAM menjadi penting dan harus membangun relationship dengan pemerintah. Tantangan ketiga adalah bagaimana membantu pemerintah dalam melaksanakan program penting untuk mempromosikan national polecy dari rekontruksi dan pembangunan. Tantangan keempat adalah bagaimana menangani masalah HAM yang tidak dikenal, yang mungkin sebagian kecil ada di wilayah peradilan pidana. Tantangan kelima adalah memasyarakatkan HAM melalüi pendidikan umum dengan menggunakan media di berbagai sekolah-sekolah, di masyarakat, di radio dan televisi. Tantangan keenam adalah bagaimana memperluas pandangan kita tentang HAM..$^{20}$ Tantangan-tantangan tersebut harus menjadi perhatian bersama sebab:

"We must therefore see human right more broadly than in the traditional role. of practricting people againt an oppressive government. Human right should also impose obligation on government and other institution of power. It now seem clear that the "final" constitution will include social and economic rights. We will have to find of using these so that they are effective, not empti promeses". 21

Bagi negara-negara yang' pemahaman dan kesadaran masyarakatnya akan HAM masih lemah, tantangan-tantangan tersebut bukan pekerjaan yang ringan. Apalagi HAM

17 Jimly Asshiddiqie, "Dimensi Konseptual dan Prosedur Pemajuan Hak Asasi Manusia Dewasa Ini (Perkembangan ke Aarah Pengertian Hak Asasi Manusia Generasi Keempat)", djsampaikan dalam diskusi terbatas di The Habibie Centre, Jakarta, April 2000.

${ }^{18}$ Neera Chandoke, Benturan Negara dan Masyarakat Sipil (The State and Civil Society), diterjemahkan oleh Yuliana-Muhammad Nastain (Yogyakarta: ISTAWA dan Penerbit Wacana, 2001), hlm. 94

${ }^{20}$ Geofi Budlendermenguraikan tantangan-tantangan melalui tulisannya"Human Rights Group Face New Chalenges In South Africa" dalam The Human Right Brief sebuah jumal yang diterbitkan oleh The Center for Human Right and Humanitarian Law. Washington College of Law, American University, Volume 3 No.2, 1996. Diakses melalui htp;//Www.wel. american sdu/pub/humrights/brieth3i2/safric32/htm, 5 Januari 2001.

$21 \mathrm{lbid}$. 
tidak hanya perlu dicantumkan dalam konstitusi atau dalam dokumen-dokumen HAM semata. Diperlukan upaya strategis dan taktis untuk mengimplementasikannya. Di beberapa negara, penanganan HAM memang tidak cukup dengan adanya badan-badan peradilan. Maka dari itu, banyak negara-negara yang membentuk komisi khusus yang menangani masalah HAM di negaranya. Komisi tersebut merupakan salah satu bentuk pelembagaan perlindungan HAM oleh lembaga independen.

\section{Paradigma Perlindungan HAM Setelah Amandemen UUD 1945}

Bersamaan dengan reformasi yang gejalanya telah muncul ke permukaan pada tahun 1997, terdapat perubahan praktek politik ketatanegaraan secara fundamental di Indonesia. Diawali dengan gerakan massa untuk menumbangkan Soeharto pada 1998, kemudian Sidang Istimewa MPR 1998, Pemillhan Umum 1999 dan Amandemen UUD 1945 pada 1999. Amandemen UUD 1945 merupakan salah satu butir tuntutan reformasi yang dipelopori oleh mahasiswa dan sebenarnya tuntután akan hal itu sudah disuarakan sejak kekuasaan Soeharto memonopoli tafsiran UUD 1945 untuk melanggengkan status quo kekuasaannya. Sejak UUD 1945 diberlakukan kembali melalui dekrit Presiden tanggal 5 Juli 1959 hingga masa kekuasaan Presiden Soeharto, praktis di bidang hukum ketatanegaraan tidak terdapat dinamika yang berarti. Pada masa inilah penguasa mengeiuarkan sikap politik bahwa UUD tidak akan merubah masyarakat, bangsa dan negaranya.

Pasal 28 UUD 1945 selain mencerminkan hak asasi generasi pertama juga telah mengadopsi hak asasi gerakan ketiga yang berbasis pada hak-hak memperoleh manfaat dari pembangunan dan hak-hak kolektif. Pasal 28D ayat (1): Hak atas pengakuan jaminan dan kepastian hukum dan perlakukan yang sama di depan hukum; ayat (2): hak bekerja, mendapat upah dan perlakuan yang adil; ayat (3): Hak memperoleh kesempatan yang sama dalam pemerintahan; ayat (4): Hak atas status kearganegaraan.

Hak-hak yang tercantum dalam Pasal 28D sebenarnya kurang sistematis. Seharusnya pasal ini lebih fokus pada perlindungan hak warga negara dalam hukum dan pemerintahan. Namun di sini terlihat pula hak mendapat pekerjaan dan memperoleh upah dan perlakuan yang adil. Secara umum pasal ini mencerminkan HAM generasi pertama.

Pasal 28E ayat (1): Hak kebebasan memeluk agama dan beribadah menurut agamanya, memilih pendidikan dan pengajaran, memilih pekerjaan, memilih kewarganegaraan, memilih tempat tinggal, meninggalkannya serta berhak kembali; ayat (2): Hak atas kebebasan meyakini kepercayaan, menyatakan pikiran, sikap sesuai hati nuraninya; ayat (3): Hak kebebasan berserikat, berkumpul dan mengeluarkan pendapat.

Hak beragama dan hak politik merupakan substansi HAM generasi pertama. Namun pengaturannya tidak harus berada dalam satu pasal. Pasal 28E sebenarnya tepat mengatur hak beragama. Namun pasal ini kurang sistematis sebab pada ayat (1) ditentukan beberapa hak yang tidak serumpun di mana hak memeluk agama juga disertai hak-hak lain di bidang pendidikan, pekerjaan dan kewarganegaraan serta hak memilih tempat tinggal. Pada ayat (2). Kebebasan menjalankan agama dan keyakinan disatukan dengan kebebasan 
menyatakan sikap dan pikiran (hak politik). Ketidak sistematisan ini juga makin terlihat pada ayat ketiganya yang berbicara tentang hak-hak politik sehingga pasal ini terkesan mencampuradukkan pengaturan agama dan keyakinan dan hak berpolitik. Seharusnya ayat ketiga berdiri sendiri. Pasal 28F: Hak berkomunikasi, memperoleh informasi, hak mencari, memperoleh, memiliki, menyimpan, mengelola dan menyampaikan informasi dengan menggunakan segala jenis saluran yang tersedia. Pasal $28 \mathrm{~F}$ ini tergolong ketentuan yang mengikuti perkembangn mutakhir di bidang pembangunan teknologi komunikasi dan informasi yang kian pesat. Hak ini sebenarnya lebih kentara pada gerakan HAM generasi ketiga. Pasal $28 \mathrm{G}$ ayat (1): Hak perlindungan diri pribadi, keluarga, kehormatan, martabat dan harta benda yang di bawah kekuasaannya, hak atas rasa aman, perlindungan dariancaman ketakutan untuk berbuat dan tidak berbuat sesuatu yang merupakan hak asasi; ayat (2); hak nbebas dari penyiksaan atau perlakuan merendahkan derajat martabat manusia dan berhak mendapat suaka politik dari negara lain. Pasal $28 \mathrm{G}$ ini masih berbasis pada HAM generasi pertamayang juga menyuarakan hak atas rasa aman, hak bebas dari rasa takut, dan hak bebas dari penyiksaan dan perlakukan yang kejam. Namun dari segi subyektif terdapat perkembangannya. Jika hak atas aman pada awalnya lebih ditekankan pada individua, kini hak tersebut meliputi keluarga, kehormatan, martabat dan harta benda yang dimilikinya.
Pasal 28H ayat (1): Hak hidup sejahtera lahir batin, bertempat tinggal, dan mendapatkan lingkungan bidup yang baik dan sehat serta hak mendapat pelayanan kesehatan; ayat (2): Hak mendapat kemudahan dan perlakuan khusus untuk memperoleh kesempatan dan sikap politik itu diperkuat dengan instrumen hukum tentang referendum terhadap perubahan UUD 1945. kenyataan itu menjadikan UUD 1945 sangat rijid ${ }^{2}$ terhadap perubahan. Maka dari itu, begitu reformasi bergulir, maka keinginan untuk mengamandemen UUD 1945 semakin tidak terbendung dan kini dalam kurun waktu yang relatif singkat, UUD 1945 telah mengalami amandemen sebanyak 3 (tiga) kali mengalami perubahan yang sangat berarti bagi perkembangan perlindungan HAM di Indonesia. Pasal tentang HAM terletak apada bab tersendiri yaitu Bab XA. Meskipun hanya terdapat pada 1 (satu) pasal yailu Pasal 28, namun pasal tersebut terdiri dari 26 butir ketentuan. Secara substansial, hak yang diatur didalamnya meliputi HAM generasi pertama hingga HAM generasi keempat. Secara singkat, HAM dalam UUD 1945 pasal 28A hingga 281 adalah sebagai berikut: Pasal 28A: Hak untuk hidup dan mempertahankan kehidupan. Pasal 28B ayat (1): Hak membentuk keluarga dan melanjutkan ketuirunan melalui perkawinan yang sah; ayat (2): Hak anak untuk kelangsungan hidup, tumbuh dan berkembang serta hak atas perlindungan dari kekerasan dan diskriminasi.

Hak hidup, hak mengembangkan diri dan hak melanjutkan keturunan merupakan HAM

\footnotetext{
${ }^{22}$ Istilah rijid ini ada dalam kategori konstitusi dilihat mudah atau tidaknya berubah. Kategori konstitusi rijid atau fleksible dilihat dari 1) apakah prosedurperubahan yang diatur di dalam pasal-pasal konstitusi memberi kemudahan pelaksanaannya atau tidak; 2) Kemauan politik penguasa untuk mengubahnya; 3) berubahnya atau tidaknya kekuatan-kekuatan riil dalam masyarakat.
} 
generasi pertama. Karena itu Pasal $28 \mathrm{~A}$ dan Pasal 28 B mewujudkan substansi hak yang disuarakan oleh generasi HAM generasi pertama. Namun demikian, ada substansi hak yang sebelumnya belum mendapatkan perhatian khusus pada HAM generasi pertama dan HAM generasi kedua, yaitu hak anak. Pasal $28 \mathrm{C}$ ayat (1): Hak setiap orang untuk mengembangkan diri, hak memperoleh pendidikan dan manfaat ilmu pengetahuan dan teknologi, seni dan budaya; ayat (2): Hak memajukan diri dalam memperjuangkan hak secara kolektif, membangunmanfaat yang sama; ayat (3): Hak atas jaminan sosial; ayat (4): Hak mempunyai hak milik atas nama pribadi dan tidak boleh diambil paksa secara sewenang-wenang.

Pasal 28H ini mencerminkan HAM genrasi kedua yang berbasis pada hak-hak sosialekonomi dan budaya serta HAM generasi keempat yang berbasis pada hak-hak dalam pembangunan dan hak-hak kolektif, termasuk di sini hak atas lingkungan hidup. Pasal 281 ayat (1): Hak untuk hidup, hak untuk tidak disiksaa, hak kemerdekaan piklran, hak beragama, hak tidak diperbudak, hak untuk diakui sebagai pribadi di hadapan hukum, hak untuk tidak dituntut atas dasar hukum yang berlaku surut adalah hak asasi yang tidak dapat dikurangi dalam keadaan apapun; ayat (2): Hak bebas dari perlakuan diskriminatif dan mendapat perlindungan dari perlakuan yang diskriminatif; ayat (4): Tanggung jawab negara, terutama pemerintah, atas perlindungan dan pemenuhan HAM; ayat (5): adanya peraturan perundang-undangan yang menjamin dan mengatur penegakan dan perlindungan HAM sesuai dengan prinsip negara hukum yang demokratis. Pasal 28 ayat (1) merupakan pasal yang mengatur hak yang termasuk non derogable rightyakni hak-hak yang tidak dapat dikurangi oleh negara dalam keadaan apapun.

Kemudian, pasal 28J sebenarnya lebih tepat disebut pasal tentang kewajiban setiap orang. Pasal ini terdiri dari dua ayat, yaitu: Pasal 28J ayat (1): Kewajiban setiap orang untuk menghormati HAM orang lain; ayat (2): Kewajiban setiap orang untuk tunduk pada pembatasan undang-undang dalam menjalankan hak dan kebebasannya.

Hak asasi manusia yang terdapat di dalam amandemen kedua UUD 1945 ternyata telah menampung baik HAM generasi pertama (hak-hak sipil dan politik) HAM generasi kedua (hak-hak sosial dan politik) maupun HAM generasi ketiga (hak-hak yang dikategorikan hak-hak kolektif).

Pengaturan HAM dalam amandemen kedua UUD 1945 tersebut juga dilandasi oleh asas non retroaktif, yaitu asas tidak dapat dituntut atas hukum yang berlaku surut. Munculnya asas ini mengejutkan banyak pihak, sebab pada saat itu tuntutan untuk mengungkap pelanggaran masa lalu tengah gencar dilakukan, seperti kasus Tanjungpriok, kasus kekerasan di Aceh selama pemberlakuan Daerah Operasi Militer (DOM) dan kasuskasus lain yang tergolong impunity. ${ }^{23}$

Perlindungan HAM dalam UUD 1945 setelah perubahan ini mencerminkan adanya keinginan yang kuat dari negara untuk lebih

${ }^{23}$ Impunity sering difahami sebagai kejahatan tanpa hukuman. Biasanya kejahatan ini dilakukan oleh aparat negara. 
memperhatikan perlindungan HAM warga negara. Sebab dalam prospektif demokrasitisasi, negaratidak sajadibangun atas dasarkekuasaan yang demokratis tetapi negara harus dibangun atas dasar pengakuan terhadap hak asasi manusia.

Dari perspektif teoritis, terdapat paradigma baru dalam perlindungan HAM di Indonesia. HAM yang dilindungi bukan hanya mencerminkan adanya positivisasi ide mengenai perlindungan hak dalam bentuk hukum dan bukan hanya HAM yang masuk dalam kategori hak-hak kodrati (seperti hak-hak untuk hidup, hak kebebasan dan hak untuk memiliki), tetapi juga hak yang masuk pengakuan akan keberagaman sosial budaya. Bahkan UUD 1945 juga mengadopsi hak-hak yang disuarakan oleh gerakan sosial modern seperti hak perempuan dan hak atas luingkungan hidup. Oleh karena itu, perlindungan HAM di Indonesia setelah UUD 1945 di amandemen mengkompromikan pandangan teoritis daari teori hukum kodrat, teori positivisme dan teori relativisme budaya. Tampaknya paradigma yang kompromis ini makin nampak pada klasifikasi hak asasi manusia berdasarkan UU . No. 39/1999 tentang Hak Asasi Manusia. Ada 10 (sepuluh) klasifikasi hak asasi yang terdapat dalam dua instrumen di atas yaitu: a) Hak untuk hidup; b) Hak berkeluarga dan melanjutkan keturunan; c) Hak mengembangkan diri; d) Hak memperoleh keadilan; $\theta$ ) Hak atas kebebasan pribadi; f) Hak atas rasa aman; g) Hak atas kesejahteraan; h) Hak turut serta dalam pemerintahan; i) Hak wanita; dan j) Hak anak.

Kini instrumen perlindungan HAM di Indonesia semakin lengkap dengan adanya TAP MPR No.XVIII/MPR/1998 tentang HAM, UU No. 39 tahun 1999 tentang HAM dan UU No. 26 tahun 2000 tentang Pengadilan HAM. Tap MPR No. XVII/MPR/1998 menyerukan bahwa penegakan HAM merupakan tanggungjawab semua elemen negara. UU No. 39 Tahun 1999 cukup komperhensif dalam mengatur HAM termasuk prosedur kelembagaan, sedangkan UU No. 26 Tahun 2000 menyebut hal baru tentang pelanggaran HAM berat yang terdiri dari kejahatan genosida dan kejahatan terhadap kemanusiaan beserta lembaga penegaknya. Dengan demikian, kekuasaan negara di Indonesia tidak hanya mengadopsi perlindungan HAM dalam konteks aturan dasarnya namun juga prosedur kelembagaannya. 0

\section{Daftar Pustaka}

Asshiddiqie, Jimly, 'Dimensi Konseptual dan Prosedural Pemajuan hak Asasi Manusia Dewasa Ini (Perkembangan ke Arah Pengertian Hak Asasi Manusia Generasi Keempat)", disampaikan dalam diskusi terbatas di The Habibie Centre, Jakarta, April 2000.

Budlender, Geoff, "Human Rights Group Face New Chalenges In South Africa" dalam Jurnal The Human Right Brief, Volume 3 No. 2, 1996.

Chandhoke, Neera, Benturan Negara dan Masyarakat Sipil (The State and Civil Siciety), diterjemah oleh YulianMuhammad Nastain, Yogyakarta: ISTAWA dan Penerbit Wacana, 2001.

Claude, Richard Pierre, and Burnst. Weston, Human Right in The World Community: Issues and Action, Philadelphia: University of Pennsylvania Press, USA, Sec- 
ond Edition, 1992.

Howard, Rhoda E., HAM, Penjelajahan Dalih Relativisme Budaya (Human Right and Search for Community) diterjemahkan oleh Nugraha Katjasungkana, Jakarta, Grafiti, 2000.

Hadis, VerdiR., Polibk Pembebasan; Teori-Teori Negara Pasca Kolonial, Yogyakarta: Pustaka.

Korten, David C., Menuju Abad ke-21, Tindakan Sukarela dan Agenda Global, Jakarta: Yayasan Obor, 2001.

Lubis, Todung Mulya, in Search of Human Rights:Legal-Political Dilemmas of Indonesia's New Order, 1966-1990, Jakarta: Gramedia Pustaka Utama dan SPES Fundation 1993.

Muladi, Hak Asasi Manusia, Politik dan
Peradilan Pidana, Semarang: Universitas Diponegoro, 1997.

Peters, A.A, dan Koesriani, Hukum dan Perkembangan Masyarakat, Jakarta: Sinar Harapan, 1988.

Vincent, Andrew, Theory Of The State. New York: Basil Blackwell, 1987.

Republik Indonesia, Undang-Undang Dasar 1945.

_._. Undang-Undang Dasar 1945 setelah Perubahan.

—_. TAP MPR No.XVII/1998 tentang Hak asasi Manusia.

—. Undang-Undang No. 39 Tahun 1999 tentang Hak Asasi Manusia.

$\longrightarrow$ Undang-Undang No. 26 Tahun 2000 tentang Pengadilan Hak Asasi Manusia

EOEOE 